\title{
PENGARUH LATIHAN DOUBLE LEG BOUND DAN KNEE TUCK JUMP TERHADAP KEMAMPUAN SMASH JUMPING
}

\author{
Oleh \\ Hendry Ismawan ${ }^{1}$, Nurjamal ${ }^{1}$, Deni Rahman Marpaung ${ }^{2}$ \\ ${ }^{1}$ Fakultas Keguruan dan Ilmu Pendidikan, Universitas Mulawarman \\ Samarinda \\ ${ }^{2}$ Fakultas Ilmu Keolahragaan, Universitas Negeri Medan \\ E-mail: hendry.ismawan@gmail.com
}

\begin{abstract}
Abstrak
Penelitian ini bertujuan untuk mengetahui pengaruh latihan Double Leg Bound dan Knee Tuck Jump terhadap kemampuan Smash Jumping pada siswa ekstakulikuler bulutangkis SMP Negeri 29 Samarinda. Jenis penelitian ini adalah penelitian eksperimen lapangan dengan teknik uji deskriptif, kolmogorov smirnov, homogenitas, paired t-tes dan independent t-tes. Populasi dalam penelitian ini adalah siswa-siswi ektrakulikuler bulutangkis SMP Negeri 29 Samarinda. Pengambilan sampel menggunakan sistem random sampling. Hasil penelitian menunjukkan bahwa Ada pengaruh latihan Double Leg Bound terhadap kemampuan Smash Jumping pada siswa ekstrakulikuler bulutangkis SMP Negeri 29 Samarinda yang diperoleh nilai thitung $=12,836>$ ttabel $=2,262$ dengan nilai probabilitas signifikansi yang diperoleh $0,000<\alpha 0,05$. Ada pengaruh latihan Kne Tuck Jump terhadap kemampuan Smash Jumping pada siswa ektrakulikuler bulutangkis SMP Negeri 29 Samarinda yang diperoleh nilai thitung = 15,213>ttabel $=2,262$ dengan nilai probabilitas signifikansi yang diperoleh $0,000<$ $\alpha$ 0,05. Ada perbedaan pengaruh latihan Double Leg Bound dan latihan Knee Tuck Jump terhadap kemampuan Smash Jumping pada siswa ekstakulikuler bulutangkis SMP Negeri 29 Samarinda, nilai rata-rata Knee Tuck Jump sebesar 15,50 > nilai rata-rata latihan Double Leg Bound sebesar 13,70, nilai kedua latihan tersebut diperoleh thitung $=2,616>$ ttabel $=2,262$ dengan nilai probabilitas signifikansi yang diperoleh $0,000<\alpha \quad 0,05$. Kesimpulannya adalah ada pengaruh dan ada perbedaan yang signifikan terhadap latihan Double Leg Bound dan latihan Knee Tuck Jump terhadap kemampuan Smash Jumping pada siswa ekstrakulikuler bulutangkis SMP Negeri 29 Samarinda.
\end{abstract}

Kata kunci: Double Leg Bound, Knee Tuck Jump, Smash Jumping.

\section{A. PENDAhuluan}

Pembangunan olahraga telah berhasil menumbuhkan budaya olahraga guna meningkatkan kualitas manusia Indonesia sehingga memiliki tingkat kesehatan dan kebugaran yang cukup harus dimulai sejak usia dini melalui pendidikan olahraga di sekolah dan masyarakat Kegiatan olahraga khususnya permainan bulutangkis merupakan salah satu dari cabang olahraga yang sangat populer di Indonesia selain itu 
juga bermanfaatkan sebagai alat pendidikan jasmani dan pembinaan mental sesuai dengan tujuan pendidikan Nasional.

Smash jumping dalam permainan bulutangkis merupakan pukulan serangan yang bertujuan untuk mematikan pertahanan lawan dan sekaligus untuk meraih poin. Pukulan smash jumping adalah suatu pukulan yang cepat, keras dan tajam, mengarah ke bidang lapangan lawan. Pukulan ini merupakan salah satu pukulan dalam permainan bulutangkis yang sering menghasilkan nilai secara langsung dalam suatu pertandingan Namun demikian seorang pemain yang ingin memiliki pukulan smash jumping yang keras dan tajam, maka pemain harus memiliki kemampuan-kemampuan tersendiri yang dapat mendukung dalam menghasilkan smash jumping yang cepat, keras dan tajam. Salah satunya yang sangat berperan adalah unsur kekuatan pada otot bagian kaki dan lengan, apalagi pemain yang melakukan smash jumping atau sambil melompat membutuhkan kemampuan otot kaki yang sangatlah baik. Faktor-faktor kelengkapan yang harus dimiliki seseorang bila ingin mencapai prestasi yang optimal yaitu : 1) pengembangan fisik, 2) pengembangan teknik, 3) pengembangan mental dan, kematangan juara (Arikunto, 2006:107).

Menurut Farentinos Radcliffe (2003:116) Perhatian khusus dalam menyikapi problem yang sering terjadi pada bulutangkis yakni pada kemampuan dalam melakukan smash jumping. Sebab, smash jumping adalah teknik yang sangat baik untuk merusak pertahanan lawan dan memperoleh point. Karena pentingnya smash jumping maka seorang atlet atau pemain bulutangkis sangat perlu mengguasai pukulan smash jumping. Oleh karena itu daya tahan kekuatan daya ledak otot tungkai melaui latihan Double Leg Bound dan Knee Tuck Jump sangat dibutuhkan dalam melakukan smash jumping yang baik.

Menurut Toni Grice (2004:18) smash jumping merupakan pukulan serangan utama dalam bulutangkis. Smash jumping dilakukan dengan kekuatan penuh atau bisa dikatakan dengan seluruh kekuatan tenaga dari pemain itu. Sedangkan menurut James Poole (2005:145) smash jumping adalah „overhead ${ }^{\text {ee }}$ yang keras diarahkan ke bawah dengan tenaga yang kuat. Smash jumping merupakan pukulan menyerang yang utama dalam bulutangkis. Menurut harsuki (2003: 21)Untuk melakukan pukulan smash jumping yang tajam (menukik) ini diperlukan suatu daya tahan kekuatan otot kaki yang baik melalui suatu latihan, yaitu latihan Double Leg Bound dan Knee Tuck Jump.Dengan 
adanya daya tahan kekuatan otot kaki yaitu daya ledak tungkai maka dapat menghasilkan kemampuan smash jumping yang lebih baik.

Dari pengamatan yang telah dilakukan, banyak siswa ekstrakulikuler bulutangkis SMP Negeri 29 Samarinda yang belum memahami tentang pentingnya latihan daya ledak tungkai melalui latihan Double Leg Bound dan Knee Tuck Jump dengan kemampuan smash jumping. Permasalahan yang timbul pada saat siswa melakukan smash jumping sangat tidak sempurna sesuai dalam melakukan lompatan yang baik sehingga banyak siswa yang melakukan smash jumping tidak keras dan tajam (menukik). Oleh karena itu, daya latihan daya ledak tungkai melalui latihan Double Leg Bound dan Knee Tuck Jump diharapkan smash jumping siswa bisa sempurna sesuai dengan yang diharapkan.

Dengan memberikan informasi tersebut diharapakan siswa dapat mengetahui seberapa penting peranan latihan daya ledak tungkai melalui latihan Double Leg Bound dan Knee Tuck Jump dalam melakukan smash jumping, bahwa dengan latihan daya

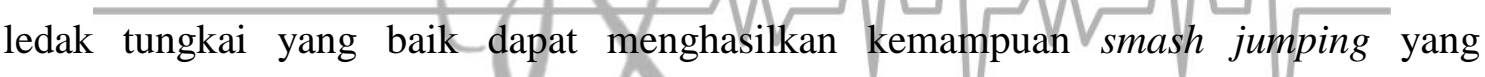
sempurna. Teknik ini merupakan salah satu yang perlu dikuasai oleh siswa dalam melakukan permainan bulutangkis yang berguna untuk memperoleh point yang diharapkan.

\section{B. METODE PENELITIAN}

Konsep prosedur penelitian mengungkapkan kegiatan populasi adalah sebagai sumber data, oleh Arikunto (1993:102) dalam bukunya menjelaskan bahwa: "Sumber data merupakan subyek dari mana data diperoleh". Hadi Sutrisno (2004:27) mengemukakan bahwa Populasi adalah keseluruhan subjek penelitian. Berdasarkan pernyataan tersebut maka populasi yang digunakan dalam penelitian ini adalah siswa ekstrakulikuler bulutangkis SMP Negeri 29 Samarinda.

Teknik pengumpulan data dalam penelitian ini adalah menggunakan teknik tes. Tes adalah serentetan pertanyaan atau latihan serta alat lain yang digunakan untuk mengukur keterampilan, pengetahuan intelegensi, kemampuan atau bakat yang dimiliki oleh individu atau kelompok. Double Leg Bound, Knee Tuck Jump, smash jumping. rumus t-test peneliti menggunakan rumus pendek adalah rumus yang serba guna dan efisien. Rumus ini dipersiapkan untuk menyelesaikan eksperimen yang mennggunakan matched subject design. 
Uji-t berpasangan $\quad t=\frac{M d}{\sqrt{\frac{\sum x d^{2}}{n(n-1)}}}$

Untuk melihat perbedaan pengaruh latihan Uji-t tidak berpasangan

$$
t=\frac{\bar{X} A 2-\bar{X} B 2}{\sqrt{\left\{\frac{\left.S d A)^{2}+S d B\right)^{2}}{n+n-2}\right\}}\left\{\frac{1}{n A}+\frac{1}{n B}\right\}}
$$

\section{HASIL DAN PEMBAHASAN PENELITIAN}

1. Hasil Penelitian

a. Pengaruh latihan Double Leg Bound terhadap kemampuan smash jumping pada siswa ekstrakulikuler bulutangkis SMP Negeri 29 Samarinda.

Hasil uji yang pertama menunjukan ada pengaruh latihan Double Leg Bound terhadap kemampuan smash jumping dalam pada siswa SMP Negeri 29 Samarinda. Terbukti bahwa nilai tobesrvasi $=\mathbf{1 2 , 8 3 6}>$ dari nilai tabel $\boldsymbol{\alpha} \mathbf{0 , 0 5}$. Hasil penelitian menunjukan bahwa latihan Double Leg Bound yang di berikan selama dua bulan pada siswa SMP Negeri 29 Samarinda memberikan pengaruh yang signifikan terhadap kemampuan smash jumping bulutangkis, hal ini dapat di jelaskan bahwa latihan Double Leg Bound bertujuan untuk melatih kekuatan terutama kekuatan otot kaki. Jika seseorang mempunyai daya tahan kekuatan otot kaki yang baik akan lebih mudah melakukan gerakan smash jumping bulutangkis ketika bermain dan dengan demikian akan meningkatkan kemampuan smash jumping bulutangkis.

Dapat diuraikan bahwa salah satu kemampuan fisik yang diperlukan dalam cabang olahraga bulu tangkis adalah kekuatan. Dilihat dari pola gerakan smash bulutangkis sangat dibutuhkan suatu komponen kondisi fisik berupa kekuatan. Kekuatan otot adalah komponen kondisi fisik seseorang tentang kemampuan dalam menggunakan untuk menerima beban sewaktu bekerja sedangkan power adalah kemampuan seseorang untuk mempergunakan kekuatan maksimum yang dikerahkan dalam waktu yang sependek-pendeknya. Kekuatan (strength) adalah komponen kondisi fisik seseorang tentang kemampuannya dalam mempergunakan otot untuk menerima beban sewaktu bekerja (Sajoto, 1995:8). berdasarkan teori di atas pentingnya untuk 
meningkatkan kekuatan otot kaki pada permainan bulutangkis maka perlunya suatau kebiasaan kearah latihan yang terus menerus dan secara berkesinambungan.

Latihan adalah suatu proses latihan yang sistematis yang dilakukan secara berulang-ulang yang semakin hari jumlah beban latihannya bertambah Dalam upaya untuk meningkatkan kemampuan fisik atau pun keterampilan pada suatu cabang olahraga, sering kali orang sudah berlatih walaupun hanya melakukan kegiatan satu atau dua kali saja setiap minggu, hal ini disebabkan karena pengertian tentang pelatihan belum dipahami dengan benar.

Latihan Double Leg Bound adalah merupakan metode latihan pliometrik untuk melatih tubuh bagian bawah. Latihan ini menargetkan otot pada paha depan, paha belakang, glutes dan betis. Latihan ini tidak memerlukan peralatan ekstra. Double Leg Bound bisa melakukannya dimana saja. Pada latihan ini, betis ikut bekerja karena latihan ini mendorong ujung kaki sejak/awal melompat (James C Radcliffe, 1985:55). Double Leg Bound adalah gerakan eksplosif. Pelaksanaannya diawali dengan sikap awal badan tegak, kedua kaki agak menekuk kebawah, kedua tangan di ayunkan kebelakang, pada saat siap kumpulan tenaga dibagian kaki, dan tolakan kedua kaki dengan setinggi mungkin, saat mendarat gunakan kedua kaki tersebut. Lakukan Double Leg Bound hanya pada permukaan yang kering. Untuk membuat otot betis bekerja lebih fokuslah pada saat melompat setinggi mungkin sebelum kita mulai melompat.

Daya ledak merupakan salah satu dari komponen gerak yang sangat penting Double Leg Bound juga adalah metode latihan yang meningkatkan daya ledak otot tungkai. untuk melakukan aktivitas yang berat karena dapat menentukan seberapa kuat orang dapat memukul, seberapa jauh orang dapat melempar, seberapa cepat dapat berlari dan lainnya. Dalam hal ini daya ledak pada latihan Double Leg Bound kemampuan seseorang dalam melatih daya ledak otot tungkai kaki dengan cara melompat ke atas setinggi mungkin untuk menghasilkan kekuatan otot kaki yang kuat dalam menunjang aktifitas kemampuan dalam melakukan smash bulutangkis. Perpaduan antara kecepatan dan daya ledak tungkai kaki akan menghasilkan kemampuan smash jumping yang baik dan terarah. Sehingga nampak kelihatan pada latihan Double Leg Bound adalah siswa menjadi semakin mampu untuk meningkatkan kemampuan adaptasinya dalam menerapkan latihan Double Leg Bound pada saat 
latihan, efek positif dari latihan ini adalah meningkatkan daya ledak otot tungkai pada olahraga bulutangkis terutama pada smash jumping.

Dengan demikian implikasi penelitian ini adalah pentingnya melatih kekuatan otot kaki dengan latihan Double Leg Bound yang meningkatkan kekuatan pada saat melakukan smash jumping bulutangkis. Salah satu yang terpenting adalah pukulan yang maksimal pada saat melakukan smash jumping bulutangkis, hal ini akibat adanya latihan Double Leg Bound yang diberikan secara berkesinambungan dalam suatu program latihan. Jadi, siswa yang di berikan latihan Double Leg Bound akan memiliki kekuatan yang baik dalam melakukan smash jumping bulutangkis tetapi bukan berarti siswa yang tidak melakukan latihan Double Leg Bound tidak memiliki kekuatan yang baik dalam melakukan smash jumping bulutangkis.

b. Pengaruh latihan Knee Tuck Jump terhadap kemampuan smash jumping pada siswa ekstrakulikuler bulutangkis SMP Negeri 29 Samarinda.

Hasil uji hipotesis yang kedua menunjukan ada pengaruh latihan Double Leg Bound terhadap kemampuan smash jumping pada siswa ekstrakulikuler bulutangkis SMP Negeri 29 Samarinda. Terbukti bahwa nilai $\mathbf{t}_{\text {obesrvasi }}=\mathbf{1 5 , 2 1 3}>$ dari nilai $\mathbf{t}_{\text {tabel }} \boldsymbol{\alpha}$ 0,05. Hasil penelitian menunjukan bahwa latihan Knee Tuck Jump yang di berikan selama dua bulan pada siswa SMP Negeri 29 Samarinda memberikan pengaruh yang signifikan terhadap kemampuan smash jumping bulutangkis. Hal ini dapat dijelaskan bahwa latihan Knee Tuck Jump bertujuan untuk melatih kekuatan terutama kekuatan otot kaki. Jika seseorang mempunyai daya tahan kekuatan otot kaki yang baik akan lebih mudah melakukan gerakan smash jumping bulutangkis ketika bermain dan dengan demikian akan meningkatkan kemampuan smash jumping bulutangkis. Hasil penelitian ini menunjukan bahwa latihan Knee Tuck Jump yang diberikan selama dua bulan pada siswa SMP Negeri 2 Samarinda memberikan pengaruh yang signifikan terhadap kemampuan smash jumping bulutangkis. Hal ini dapat dijelaskan karena latihan Knee Tuck Jump bertujuan untuk melatih kekuatan terutama kekuatan otot tungkai. Jika seseorang mempunyai daya tahan kekuatan otot tungkai yang baik akan lebih mudah melakukan gerakan loncatan smash jumping bulutangkis ketika bermain dan dengan demikian akan dapat meningkatkan kemampuan siswa dalam melakukan smash jumping bulutangkis. 


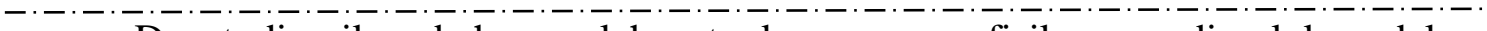

Dapat diuraikan bahwa salah satu kemampuan fisik yang diperlukan dalam cabang olahraga bulutangkis pada pelaksanaan smash jumping bulutangkis adalah kualitas otot tungkai yang baik. Kekuatan otot tungkai yang diperlukan pada saat memukul bola dan melewatkannya pada net dengan kondisi ini kualitas smash jumping bulutangkis yang diperagakan oleh siswa dapat menjadi lebih baik. Yang nampak kelihatan pada latihan Knee Tuck Jump adalah siswa menjadi semakin meningkatkan kemampuan adaptasinya dalam menerapkan latihan Knee Tuck Jump pada saat latihan. Dengan demikian, daya ledak merupakan unsur yang sangat menentukan dalam penampilan olahraga terutama pada cabang olahraga yang mengarahkan tenaga secara cepat seperti smash jumping bulutangkis, bahwa "latihan adalah proses yang sistematis dari berlatih atau bekerja yang dilakukan secara berulang ulang dengan kian hari kian menambah jumlah beban latihan atau pekerjaaannya".menyatakan bahwa yang di maksud dengan latihan adalah"proses yang sistematis dari kerja fisik yang dilakukan secara berulang-ulang dengan setiap hari menambah/jumlah beban pekerjaannya". Yang dimaksud dengan sistematis adalah: Latihan yang dilaksanakan secara teratur, terjadwal, dan berkesinambungan dari yang sederhana keyang lebih kompleks. Berulang-ulang mempunyai arti bahwa gerakan-gerakan yang dilatih harus dilakukan secara berulangulang sehingga menjadi lebih otomatis dan refleksi dalam pelaksanaannya. Dalam menciptakan suatu kekuatan dalam loncatan smash bulutangkis tidak akan bisa tanpa didasari adanya kekuatan otot tungkai dan latihan yang sistematis. Kekuatan merupakan komponen kondisi fisik yang perlu mendapat perhatian khusus dan merupakan prioritas utama dalam meningkatkan hasil kekuatan otot tungkai dalam melakukan smash jumping bulutangkis. Pada umumnya dalam melakukan smash jumping bulutangkis tampa mempunyai kekuatan otot tungkai maka hasil smash jumping bulutangkis tidak maksimal sehingga perlunya dilakukan latihan yang mengarah pada kekuatan otot tungkai dengan latihan Knee Tuck Jump.

Dari data hasil penelitian setiap minggunya terdapat perubahan pada sampel yang lebih membaik, hal ini dikarenakan latihannya secara teratur. Proses latihan Knee Tuck Jump dilakukan selama 2 bulan dalam waktu yang singkat itu sudah menunjukan peningkatan dari hasil smash jumping bulutangkis. Untuk meningkatkan kekuatan program latihan yang tepat yaitu menggunakan latihan dengan ulangan yang sedikit. 
Mengemukakan bahwa "Kekuatan adalah kemampuan seseorang untuk menggunakan ototnya dalam menerima beban sewaktu bekerja".

Dengan demikian implikasi penelitian ini adalah pentingnya melatih kekuatan otot kaki dengan latihan Knee Tuck Jump yang meningkatkan kekuatan pada saat melakukan melakukan lompatan dalam melakukan smash jumping. Salah satu yang terpenting adalah adanya daya ledak pada saat melakukan lompatan, hal ini akibat adanya latihan Knee Tuck Jump yang diberikan secara berkesinambungan dalam suatu program latihan. Jadi siswa yang diberikan latihan Knee Tuck Jump akan memiliki lompatan yang baik dalam melakukan smash jumping, tetapi bukan berarti siswa yang tidak melakukan latihan Knee Tuck Jump tidak memiliki lompatan yang baik dalam melakukan smash jumping bulutangkis.

c. Perbedaan pengaruh latihan Doble Leg Bound dan Knee Tuck Jump Terhadap Kemampuan Smash Jumping Pada Siswa Ekstrakurikuler Bulutangkis SMP Negeri 29 Samarinda.

Kemudian dari hasil pengujian analisis data, ada perbedaan pengaruh latihan Double Leg Bound dan latihan Knee Tuck Jump terhadap kemampuan smash jumping dalam permainan bulutangkis pada siswa SMP Negeri 29 Samarinda dan latihan Double Leg Bound tidak lebih baik jika dibandingkan dengan latihan Knee Tuck Jump hal ini dibuktikan oleh nilai $t_{\text {hitung }}=\mathbf{2 , 6 1 6}>$ dari nilai $\mathbf{t}_{\text {tabel }} \boldsymbol{\alpha} \mathbf{0 , 0 5}=\mathbf{2 . 2 6 2}$. Di samping itu nilai rata-rata tes akhir smash jumping bulutangkis dengan latihan Double Leg Bound dan nilai rata - rata tes akhir latihan Knee Tuck Jump berbeda secara nyata. Smash jumping bulutangkis dengan menggunakan latihan Double Leg Bound tidak lebih baik dibandingkan dengan latihan smash jumping bulutangkis dengan latihan Knee Tuck Jump. Dapat diuraikan bahwa hasil penelitian antara latihan Double Leg Bound dan latihan Knee Tuck Jump sama-sama memberikan pengaruh yang signifikan terhadap kemampuan smash jumping dalam permainan bulutangkis, apabila pengaruhnya dilihat dari perbedaan hasil antara tes awal dan tes akhir setelah dilakukan treatment. Akan tetapi setelah dilakukan uji perbedaan kedua bentuk latihan tersebut menunjukkan pengaruh terhadap kemampuan smash jumping bulutangkis, dengan latihan Knee Tuck Jump lebih baik terhadap hasil kemampuan smash jumping bulutangkis dibandingkan dengan latihan Double Leg Bound terhadap kemampuan smash jumping bulutangkis 
yang dicapai siswa baik dari segi perbedaan rata-rata pencapaiannya maupun hasil dari uji beda kedua bentuk latihan tersebut.

Dalam melakukan kedua variabel latihan dari sampel 20 siswa dilakukan machid ordinat dan terpilih 10 siswa dari masing-masing kedua kelompok latihan tersebut. Pada saat siswa melakukan latihan terdapat beberapa siswa yang serius dan kurang serius dalam melakukan latihan. Pada latihan Double Leg Bound keadaan siswa sama dengan latihan Knee Tuck Jump hanya saja perbedaannya dapat dilihat dari nilai selisih atau peningkatan yang dilakukan siswa dalam melakukan latihan. Ditinjau dari perbedaan proses latihan baik latihan Double Leg Bound dan latihan Knee Tuck Jump.

Dalam melakukan gerakan smash jumping gerak yang terjadi adalah gerak kelenturan, kekuatan otot tungkai serta koordinasi gerak tubuh yang saling berhubungan sehingga menghasilkan gerakan smash jumping yang tepat pada sasaran yang ingin dituju. Diliat dari analisa smash jumping dibutuhkannya latihan untuk menunjang tercapainya suatu hasil yang efektif dan efesien yang mana tekhnik latihan Double Leg Bound dan latihan Knee Tuck Jump untuk membentuk kekuatan komponen otot sehingga dapat menunjang aktifitas gerak seseorang dalam melakukan olahraga khususnya cabang olahraga bulutangkis. Jadi, kekuatan otot tungkai sangatlah berpengaruh terhadap kemapuan smash jumping bulutangkis. Oleh karena itu apabila siswa memiliki kekuatan otot tungkai yang baik maka diduga akan menunjukan pengaruh yang berarti dalam melakukan smash jumping bulutangkis.

Diantara komponen fisik yang mendukung kemampuan smash seseorang yaitu daya ledak atau power karena dalam melakukan smash bulutangkis tumpuannya adalah kaki. Oleh karena itu daya ledak (power) merupakan salah satu syarat untuk tinggi dan rendahnya lompatan seseorang. Daya ledak tungkai yang juga dikenal dengan istilah tenaga eksplotif atau power yang sangat diperlukan dalam berbagai cabang olahraga dan seperti bulutangkis.

Daya ledak otot atau Muscular Power adalah kemampuan seseorang untuk melakukan kekuatan maksimum dengan usahanya yang dikerahkan dalam waktu sependek-pendeknya. Dalam hal ini dapat dikemukakan bahwa, daya ledak otot atau power $=$ Kekuatan atau Force $\mathrm{X}$ Kecepatan atau Velocity $(\mathrm{P}=\mathrm{F} \mathrm{X} \mathrm{T})$. Sedangkan menurut Harsono (1988:200) mengatakan power atau daya ledak adalah kemampuan otot untuk mengerahkan kekuatan secara maksimal dalam waktu yang sangat cepat. 
Oleh karena itu, pemain bulutangkis tidak cukup hanya sekedar berlatih untuk meningkatkan kekuatannya saja akan tetapi, kekuatan tersebut harus dapat dipadukan dengan kecepatan sehingga menjadi apa yang disebut power.

Bila perpaduan antara kecepatan dan daya ledak baik maka pukulan smash yang dihasilkan akan menjadi lebih keras dan tajam pada saat melakukannya. Dengan demikian, daya ledak merupakan unsur yang sangat menentukan dalam penampilan olahraga terutama pada cabang olahraga yang mengerahkan tenaga secara cepat. Seperti smash pada bulutangkis adalah suatu gerakan yang memerlukan kekuatan dan kecepatan pada saat mengambil awalan kemudian melakukan pukulan yang membutuhkan gerakan yang cepat.

Oleh sebab itu, seseorang tidak cukup sekedar berlatih untuk meningkatkan kekuatannya saja akan tetapi, kekuatan tersebut haruslah ditingkatkan menjadi apa yang disebut sebagi power. Power lebih diperlukan dan boleh dikatakan semua cabang olahraga seperti bulutangkis karena didalam power ada kekuatan dan kecepatan. daya ledak adalah berhubungan dengan laju ketika seseorang melakukan kegiatan atau daya ledak merupakan hasil dari daya $\mathrm{X}$ percepatan (force $X$ velocity). Perpaduan kekuatan dan kecepatan inilah yang ditunjukkan dalam aktifitas yang di butuhkan para pemain bulutangkis dalam melakukan smash. Kecepatan kontraksi otot dibutuhkan dalam melakukan gerakan yang koordinasi sebaik-baiknya yang dipergunakan otot untuk menentukan derajat kekuatan individu.

Berdasarkan beberapa pendapat di atas, maka daya ledak merupakan komponen dasar motorik atau kemampuan dalam olahraga, yaitu perpaduan antara kekuatan dan kecepatan sehingga menghasilkan kontraksi otot pada saat melakukan lompatan smash dalam bulutangkis. Oleh sebab itu, untuk melatih power tersebut perlu sebuah latihan, yaitu dengan latihan Knee Tuck Jump karena latihan Knee Tuck Jump sangat diperlukan dalam berbagai cabang olahraga dan tidak terkecuali dalam permainan bulutangkis. Menurut Engkos Kosasih (1993:249) Knee Tuck Jump adalah suatu bentuk latihan explosive power training yang dilakukan dengan lompat ke atas dengan tolakan kedua kaki, posisi kaki dilipat tinggi dan telapak tangan menyentuh lutut. Oleh karena itu, latihan Knee Tuck Jump manfaatnya untuk meningkatkan daya ledak tungkai yang sangat diperlukan dan sangat menentukan tinggi lompatan seorang pemain bulutangkis. Dimana pada waktu melakukan smash yang baik tajam (menukik) ke daerah lawan yang 
sekaligus bisa mengarahkan sesuai dengan kehendak si pelaku smash, maka lompatan yang dilakukan harus tinggi dan baik sehingga menyulitkan lawan untuk menerimanya dan mengembalikannya kembali maka diperlukan latihan Knee Tuck Jump agar power dapat meningkat.

\section{KESIMPULAN}

Berdasarkan analisis data dan pembahasannya maka hasil penelitian ini dapat disimpulkan sebagai berikut:

1. Ada pengaruh yang signifikan latihan Double Leg Bound terhadap kemampuan Smash jumping pada siswa ekstrakulikuler bulutangkis SMP Negeri 29 Samarinda.

2. Ada pengaruh yang signifikan latihan Knee Tuck Jump terhadap terhadap kemampuan Smash jumping pada siswa ekstrakulikuler bulutangkis SMP Negeri 29 Samarinda.

3. Ada perbedaan pengaruh yang signifikan antara latihan Double Leg Bound dan latihan Knee Tuck Jump terhadap kemampuan Smash jumping pada siswa ekstrakulikuler bulutangkis SMP 29 Samarinda.

\section{Daftar Pustaka}

Arikunto, Suharsimi. 2006. Prosedur Penelitian Suatu Pendekatan Praktik. Jakarta: PT. Rineke Cipta

Grice, Toni. 2004. Bulutangkis Petunjuk Praktis Untuk Pemula dan Lanjut. Jakarta: PT. Raja Grafindo Persada

Groser, strarischka, zimerman. 2001. Latihan Fisik Olahraga. Terjemahan Paulus Levinus Pasurrney. Jakarta: KONI Pusat

Harsuki. 2003. Perkembangan Olahraga Terkini Kajian Pakar-Pakar. Jakarta: PT. Raja Grafindo Persada

Muhajir. 2007. Pendidikan Jasmani Olahraga dan Kesehatan Untuk SMA Kelas X. Jakarta: Erlangga

Poole, James. 2005. Belajar Bulutangkis. Bandung: CV. Pionir Jaya

Radcliffe JC and Farentinos RC. 2003. Plyometrics Exsplosive Power Training 2 ed. Campingn, Illionis: Human Kinetics Published, inc

Sutrisno, Hadi. 2004. Metodologi Research. Jilid IV. Yogyakarta. UG 